\title{
LUNG AND CHEST WALL COMPLIANCE OF APNEIC PARALYZED INFANTS *
}

\author{
By CHARLES C. RICHARDS AND LEONARD BACHMAN
}

(From the Division of Anesthesiology, The Children's Hospital of Philadelphia, and The School of Medicine, University of Pennsylvania, Philadelphia, Pa.)

(Submitted for publication July 28, 1960 ; accepted October 17, 1960)

The total respiratory compliance of anesthetized, relaxed adults has been found to have a lower value than that in awake subjects $(1,2)$. The probable explanation for this fact is the inability of the conscious individual to relax as completely as does the anesthetized patient. The values observed in unconscious subjects, therefore, more closely approximate those of narcotized patients in need of artificial respiration $(1,2)$ or of unanesthetized, apneic polio patients being ventilated by a mechanical respirator (3).

The pulmonary compliance of resting newborn infants has been measured by the use of a body plethysmograph and intraesophageal pressure technique $(4,5)$. These values are low when compared on a lung weight basis to those recorded for the adult. However, since lung compliance relates closely to the functional residual capacity $(4,6,7)$, a comparison of infant and adult lungs on this basis suggests that they are similar in compliance.

We have been unable to find any report of measurements of total lung and chest wall compliance in the anesthetized, paralyzed infant. This is a report of our endeavor to obtain such information, which, we believe, will provide a better understanding of infant respiratory physiology. These data also are of practical interest for infant resuscitation, anesthesia, and in the design of infant resuscitators.

\section{METHODS}

The 21 infants selected for this study varied in age from 5 to 76 days and in weight from 5.5 to 12.5 pounds. Three of the infants were females. All appeared free of respiratory disease as far as could be determined by history and physical examination. None exhibited abdominal distention. All were scheduled for pyloroplasty or inguinal hernioplasty, except one who was to have a liver

* This study was supported in part by Research Grant no. B-2043 (Cl) from the National Institutes of Health, Bethesda, Md. biopsy and one excision of a sacral cyst. Three infants were premature at birth.

The apparatus (Figure 1) consisted of an oxygen cylinder with pressure-reducing valve and flow-regulator (a flow-regulating valve designed to deliver gas constantly at a selected pressure), a large-bore two-way stopcock and a calibrated, low-inertia water spirometer of approximately $450 \mathrm{ml}$ capacity. These were connected by large-bore, smooth rubber tubing to permit inflation of the infant's lungs with oxygen through one limb of the two-way stopcock, then rapid collection of the passively expired gas in the spirometer through the other limb. The "compliance" of the rubber components of the equipment was negligible at the highest pressure.

All infants were studied in the operating room just prior to operation. Premedication consisted of atropine sulfate, $0.15 \mathrm{mg}$, given intramuscularly 38 to 126 minutes before the start of anesthesia. The infants were placed in a supine position on the operating table, and were then allowed to inhale a mixture of 40 per cent cyclopropane in oxygen via a face mask and bag. Anesthetic inhalation continued until the infant stopped moving and appeared to lose consciousness, usually 1 to 2 minutes ( 3 minutes for one infant and 4 minutes for another). At this point, succinylcholine chloride, 2.0 to $3.8 \mathrm{mg}$ per

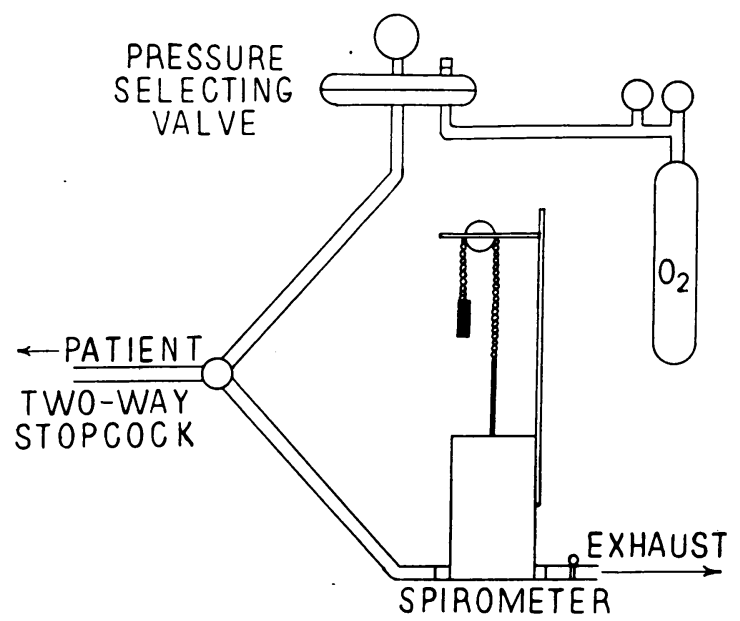

Fig. 1. Diagram of apparatus used for total comPLIANCE MEASUREMENTS. The infant's lungs were inflated for 10 seconds at the selected airway pressure, then the stopcock was turned rapidly to collect the passively expired gas in the spirometer. 
pound of body weight, was administered intramuscularly and the cyclopropane was turned off. One infant required two doses of succinylcholine, totaling $5.8 \mathrm{mg}$ per pound of body weight. As apnea developed, usually within 1 to 3 minutes, the infant's respirations were gently assisted, then controlled, with oxygen. Endotracheal intubation was accomplished with a close-fitting tube within 5 minutes of the injection of succinylcholine. Immediately thereafter, a nasogastric catheter was passed to assure deflation of the stomach while the lungs were gently ventilated with oxygen. Compliance measurements were commenced within 1 to 2 minutes after the tracheal intubation, and each study required less than 5 minutes to complete, during which time respiratory activity returned in only one infant. In view of the brief duration of cyclopropane administration, and the 3 to 6 minutes of washout with oxygen before beginning the study, the concentration of cyclopropane in the infant during the measurements was considered to be negligible.

The procedure consisted of inflating the infant's lungs with oxygen for 10 seconds at five different airway pressures and collecting the passively expired oxygen in the spirometer after each inflation. The infant's lungs thus deflated to their resting expiratory level after each volume

TABLE I

Physical characteristics, succinylcholine dosage and total respiratory compliance data for 21 normal infants

\begin{tabular}{|c|c|c|c|c|c|c|c|c|c|c|c|}
\hline \multirow[b]{2}{*}{$\begin{array}{c}\text { Patient } \\
\text { no. }\end{array}$} & \multirow[b]{2}{*}{ Age } & \multirow[b]{2}{*}{ Wt } & \multirow[b]{2}{*}{$\mathrm{Ht}$} & \multirow[b]{2}{*}{$\begin{array}{l}\text { Dose of } \\
\text { succinyl- } \\
\text { choline }\end{array}$} & \multicolumn{6}{|c|}{ Total compliance $\left(\mathrm{ml} / \mathrm{cm} \mathrm{H}_{2} \mathrm{O}\right)$} & \multirow[b]{2}{*}{ Series order } \\
\hline & & & & & $\begin{array}{l}\text { At } 6.8-8.2 \\
\mathrm{~cm} \mathrm{H} \mathrm{H}_{2} \mathrm{O}\end{array}$ & $\begin{array}{l}\text { At } 13.6 \\
\mathrm{~cm} \mathrm{H}_{2} \mathrm{O}\end{array}$ & $\begin{array}{l}\text { At } 20.4 \\
\mathrm{~cm} \mathrm{H}_{2} \mathrm{O}\end{array}$ & $\begin{array}{l}\text { At } 27.2 \\
\mathrm{~cm} \mathrm{H}_{2} \mathrm{O}\end{array}$ & $\begin{array}{c}\text { At } 30.0- \\
31.2 \\
\mathrm{~cm} \mathrm{H}_{2} \mathrm{O}\end{array}$ & 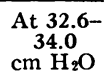 & \\
\hline & days & $l b s, o z$ & $\mathrm{~cm}$ & $m g / l b$ & & & & & & & \\
\hline $1 *$ & 43 & 5,8 & 49 & 3.3 & $\begin{array}{l}3.3 \\
3.3\end{array}$ & $\begin{array}{l}5.1 \\
3.3\end{array}$ & $\begin{array}{l}4.9 \\
3.6\end{array}$ & $\begin{array}{l}4.4 \\
3.9\end{array}$ & & $\begin{array}{l}4.1 \\
3.9\end{array}$ & $\begin{array}{l}\text { a. Descending } \\
\text { b. Ascending }\end{array}$ \\
\hline 2 & 5 & 6,0 & 47 & 3.0 & $\begin{array}{l}4.7 \dagger \\
4.0 \dagger\end{array}$ & $\begin{array}{l}5.0 \\
4.5\end{array}$ & $\begin{array}{l}5.1 \\
4.9\end{array}$ & $\begin{array}{l}5.0 \\
4.9\end{array}$ & & $\begin{array}{l}4.5 \ddagger \\
4.9 \ddagger\end{array}$ & $\begin{array}{l}\text { a. Descending } \\
\text { b. Ascending }\end{array}$ \\
\hline 3 & 44 & 6,10 & 51 & 3.0 & $\begin{array}{l}6.5 \\
6.3\end{array}$ & $\begin{array}{l}6.6 \\
6.2\end{array}$ & $\begin{array}{l}5.7 \\
5.4\end{array}$ & $\begin{array}{l}5.1 \\
4.9\end{array}$ & & $\begin{array}{l}4.8 \\
4.6\end{array}$ & $\begin{array}{l}\text { a. Descending } \\
\text { b. Ascending }\end{array}$ \\
\hline 4 & 34 & 6,11 & 52 & 3.0 & $\begin{array}{l}5.6 \\
5.6\end{array}$ & $\begin{array}{l}6.1 \\
6.1\end{array}$ & $\begin{array}{l}5.3 \\
4.8\end{array}$ & $\begin{array}{l}4.6 \\
4.7\end{array}$ & $\begin{array}{l}4.6 \S \\
4.58\end{array}$ & & $\begin{array}{l}\text { a. Descending } \\
\text { b. Ascending }\end{array}$ \\
\hline 5 & 46 & 6,12 & & 2.1 & $\begin{array}{l}7.1 \\
7.1\end{array}$ & $\begin{array}{l}5.5 \\
7.0\end{array}$ & $\begin{array}{l}4.7 \\
5.7\end{array}$ & $\begin{array}{l}4.5 \\
5.1\end{array}$ & $\begin{array}{l}4.6 \S \\
5.2\end{array}$ & & $\begin{array}{l}\text { b. Ascending } \\
\text { a. Ascending }\end{array}$ \\
\hline 6 & 23 & 7,0 & 50 & 3.6 & $\begin{array}{l}6.5 \\
6.5\end{array}$ & $\begin{array}{l}7.3 \\
7.0\end{array}$ & $\begin{array}{l}6.2 \\
6.2\end{array}$ & $\begin{array}{l}5.7 \\
5.7\end{array}$ & & $\begin{array}{l}5.1 \\
5.1\end{array}$ & $\begin{array}{l}\text { a. Descending } \\
\text { b. Ascending }\end{array}$ \\
\hline 7 & 46 & 7,6 & 52 & 3.4 & $\begin{array}{l}7.4 \\
7.4\end{array}$ & $\begin{array}{l}7.0 \\
7.0\end{array}$ & $\begin{array}{l}6.5 \\
6.0\end{array}$ & $\begin{array}{l}5.3 \\
5.1\end{array}$ & & $\begin{array}{l}5.1 \ddagger \\
5.1 \ddagger\end{array}$ & $\begin{array}{l}\text { a. Descending } \\
\text { b. Ascending }\end{array}$ \\
\hline $8 \|$ & 20 & 7,12 & 55 & 3.8 & $\begin{array}{l}5.7 \\
5.7\end{array}$ & $\begin{array}{l}7.0 \\
6.2\end{array}$ & $\begin{array}{l}5.7 \\
5.4\end{array}$ & $\begin{array}{l}5.1 \\
5.1\end{array}$ & & $\begin{array}{l}4.6 \\
4.7\end{array}$ & $\begin{array}{l}\text { a. Descending } \\
\text { b. Ascending }\end{array}$ \\
\hline 9 & 45 & 8,4 & & 2.2 & $\stackrel{5.6}{(5.1) \dagger}$ & $\begin{array}{c}5.7 \\
(5.5)\end{array}$ & $\begin{array}{c}4.7 \\
(4.4)\end{array}$ & $\begin{array}{c}4.3 \\
\text { (Breathing) }\end{array}$ & 4.4 & & $\begin{array}{l}\text { b. Ascending } \\
\text { a. (Not incl.) }\end{array}$ \\
\hline $10 \|$ & 26 & 8,4 & & 2.0 & $\begin{array}{l}3.4 \\
5.1\end{array} \dagger$ & $\begin{array}{l}3.1 \\
5.1\end{array}$ & $\begin{array}{l}2.6 \\
4.4\end{array}$ & $\begin{array}{l}2.9 \\
4.3\end{array}$ & 4.8 & $4.4 \ddagger$ & $\begin{array}{l}\text { b. Ascending } \\
\text { a. Ascending }\end{array}$ \\
\hline 11 & 28 & 8,4 & 54 & 2.0 & $\begin{array}{l}6.5 \\
6.2\end{array}$ & $\begin{array}{l}7.0 \\
6.6\end{array}$ & $\begin{array}{l}5.7 \\
5.5\end{array}$ & $\begin{array}{l}4.9 \\
4.9\end{array}$ & & $\begin{array}{l}4.4 \ddagger \\
4.6\end{array}$ & $\begin{array}{l}\text { a. Descending } \\
\text { b. Ascending }\end{array}$ \\
\hline $12 \|$ & 40 & 8,14 & 49 & 3.4 & $\begin{array}{l}3.2 \\
3.2\end{array}$ & $\begin{array}{l}4.6 \\
4.1\end{array}$ & $\begin{array}{l}4.1 \\
3.6\end{array}$ & $\begin{array}{l}3.6 \\
3.6\end{array}$ & & $\begin{array}{l}3.7 \\
3.7\end{array}$ & $\begin{array}{l}\text { a. Descending } \\
\text { b. Ascending }\end{array}$ \\
\hline $13^{*}$ & 55 & 9,1 & 52 & 3.3 & $\begin{array}{l}4.1 \\
3.3\end{array}$ & $\begin{array}{l}4.3 \\
3.9\end{array}$ & $\begin{array}{l}3.9 \\
3.4\end{array}$ & $\begin{array}{l}3.7 \\
3.5\end{array}$ & & $\begin{array}{l}3.6 \ddagger \\
3.9 \ddagger\end{array}$ & $\begin{array}{l}\text { a. Descending } \\
\text { b. Ascending }\end{array}$ \\
\hline $14^{*}$ & 76 & 9,4 & 54 & 2.7 & $\begin{array}{l}4.1 \\
4.1\end{array}$ & $\begin{array}{l}5.9 \\
5.1\end{array}$ & $\begin{array}{l}4.9 \\
4.2\end{array}$ & $\begin{array}{l}4.3 \\
3.9\end{array}$ & & $\begin{array}{l}3.9 \ddagger \\
4.1 \ddagger\end{array}$ & $\begin{array}{l}\text { a. Descending } \\
\text { b. Ascending }\end{array}$ \\
\hline 15 & 58 & 9,15 & & 2.5 & $\begin{array}{l}4.0 \dagger \\
5.4 \dagger\end{array}$ & $\begin{array}{l}4.6 \\
6.9\end{array}$ & $\begin{array}{l}4.1 \\
5.9\end{array}$ & $\begin{array}{l}4.6 \\
5.7\end{array}$ & 5.8 & $5.7 \ddagger$ & $\begin{array}{l}\text { b. Ascending } \\
\text { a. Ascending }\end{array}$ \\
\hline 16 & 43 & 10,12 & 57 & 2.3 & $\begin{array}{l}4.8 \\
4.8\end{array}$ & $\begin{array}{l}6.6 \\
5.5\end{array}$ & $\begin{array}{l}5.4 \\
4.7\end{array}$ & $\begin{array}{l}4.9 \\
5.1\end{array}$ & & $\begin{array}{l}4.9 \ddagger \\
5.1 \ddagger\end{array}$ & $\begin{array}{l}\text { a. Descending } \\
\text { b. Ascending }\end{array}$ \\
\hline 17 & 28 & 11,4 & 52 & $\left.\begin{array}{l}3.2 \\
2.6\end{array}\right\} 5.8$ & $\begin{array}{l}4.1 \\
4.1\end{array}$ & $\begin{array}{l}5.9 \\
4.6\end{array}$ & $\begin{array}{l}5.3 \\
4.1\end{array}$ & $\begin{array}{l}4.9 \\
4.5\end{array}$ & & $\begin{array}{l}4.7 \\
4.9\end{array}$ & $\begin{array}{l}\text { a. Descending } \\
\text { b. Ascending }\end{array}$ \\
\hline 18 & 64 & 11,8 & 57 & 2.6 & $\begin{array}{l}4.1 \dagger \\
5.0\end{array}$ & $\begin{array}{l}4.7 \\
6.2\end{array}$ & $\begin{array}{l}4.5 \\
5.8\end{array}$ & $\begin{array}{l}4.7 \\
5.5\end{array}$ & & $\begin{array}{l}5.8 \ddagger \\
5.8 \ddagger\end{array}$ & $\begin{array}{l}\text { b. Ascending } \\
\text { a. Ascending }\end{array}$ \\
\hline 19 & 51 & 11,10 & 57 & 2.6 & $\begin{array}{l}4.8 \dagger \\
4.1 \dagger\end{array}$ & $\begin{array}{l}6.7 \\
5.6\end{array}$ & $\begin{array}{l}6.1 \\
5.0\end{array}$ & $\begin{array}{l}5.6 \\
5.0\end{array}$ & & $\begin{array}{l}5.2 \ddagger \\
5.5 \ddagger\end{array}$ & $\begin{array}{l}\text { a. Descending } \\
\text { b. Ascending }\end{array}$ \\
\hline 20 & 40 & 11,12 & 58 & 3.1 & $\begin{array}{l}5.6 \\
5.6\end{array}$ & $\begin{array}{l}7.6 \\
6.9\end{array}$ & $\begin{array}{l}7.0 \\
5.9\end{array}$ & $\begin{array}{l}6.2 \\
6.0\end{array}$ & & $\begin{array}{l}5.7 \\
5.8\end{array}$ & $\begin{array}{l}\text { a. Descending } \\
\text { b. Ascending }\end{array}$ \\
\hline 21 & 46 & 12,8 & 61 & 3.2 & $\begin{array}{l}4.1 \\
4.1\end{array}$ & $\begin{array}{l}5.9 \\
4.6\end{array}$ & $\begin{array}{l}5.1 \\
4.1\end{array}$ & $\begin{array}{l}4.5 \\
4.1\end{array}$ & & $\begin{array}{l}4.2 \\
4.2\end{array}$ & $\begin{array}{l}\text { a. Descending } \\
\text { b. Ascending }\end{array}$ \\
\hline Average & & & & & 5.2 & 6.2 & 5.4 & 4.9 & 4.9 & 4.7 & a. Descending \\
\hline $\mathrm{SD}$ & & & & & \pm 1.0 & \pm 0.9 & \pm 0.9 & \pm 0.8 & \pm 0.4 & \pm 0.6 & ascending \\
\hline $\begin{array}{l}\text { Average } \\
\text { SD }\end{array}$ & & & & & $\begin{array}{r}4.9 \\
\pm 1.2\end{array}$ & $\begin{array}{r}5.2 \\
\pm 1.4\end{array}$ & $\begin{array}{r}4.6 \\
\pm 1.0\end{array}$ & $\begin{array}{r}4.6 \\
\pm 0.4\end{array}$ & $\begin{array}{r}4.8 \\
\pm 0.8\end{array}$ & $\begin{array}{r}4.7 \\
\pm 0.8\end{array}$ & b. Ascending \\
\hline
\end{tabular}

* Premature at birth. 

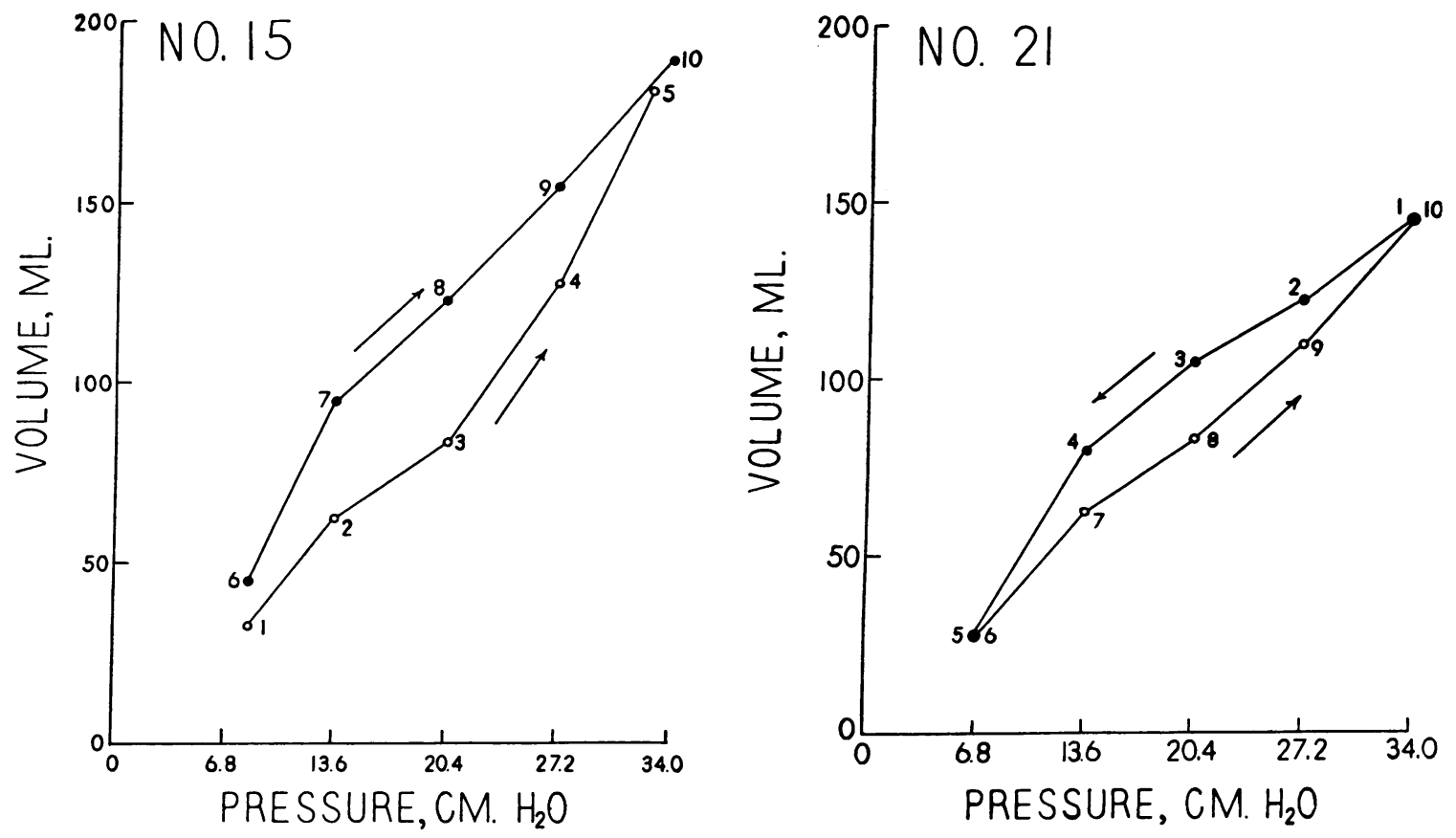

Fig. 2. Representative pressure-volume curves. The volume measurements are numbered in the sequential order of study. The effect of a previously higher airway pressure on a subsequent measurement is apparent for each infant in the differences between the curves.

measurement and were reinflated from this level during the succeeding application of pressure. The endotracheal tube fit snugly enough in the larynx to prevent gas leaks at the highest airway pressures. Spirometer collection times at each pressure were about 4 to $6 \mathrm{sec}-$ onds, ample time to insure no further gas flow from the lungs. Expired volumes were corrected to BTPS.

Two volume measurements were made at each airway pressure. Five infants were studied, starting at the lowest pressure and progressing to the highest pressure, then repeating the series in the same order. The remainder of the infants were studied by starting at the highest pressure and progressing to the lowest pressure, then repeating the series in the reverse order. The pressures chosen were 6.8, 13.6, 20.4, 27.2 and $34.0 \mathrm{~cm} \mathrm{H}_{2} \mathrm{O}$; these correspond to $5,10,15,20$ and $25 \mathrm{~mm} \mathrm{Hg}$, respectively. A few measurements were made at $8.2,30.0,31.2$ or 32.6 cm $\mathrm{H}_{2} \mathrm{O}$.

\section{RESULTS}

Compliance values for the lungs and thorax at each airway pressure are listed in Table I. An individual value for compliance represents the ratio of the volume expired to the airway pressure applied immediately preceding the expiration. Compliance was noted to be higher when measurements were made starting at a high pressure and progressing to a low pressure, or when a second ascending series of pressures followed immediately after the highest pressure of the previous ascending series.

Two representative pressure-volume curves are shown (Figure 2). The volume measurements are numbered in the sequential order of study; thus, in Infant 15 both studies were ascending in order, and in Infant 21 the first study was descending in order and the second was ascending.

The compliance averages at the various pressures for each type of series, together with the standard deviation of compliance values, are presented at the bottom of Table I. These averages have been plotted graphically against the airway pressures used (Figure 3). The fact that higher compliance values resulted when measurements were made following a higher airway pressure is clearly demonstrated by the differences between the curves. These differences were most marked at pressures of 13.6 and $20.4 \mathrm{~cm} \mathrm{H}_{2} \mathrm{O}(\mathrm{p}<0.01$ and $\mathrm{p}<0.02$, respectively ${ }^{1}$ ). The curves approached one another at the pressure extremes.

Comparisons of data from individual infants can be made at the compliance values obtained at 20.4 $\mathrm{cm} \mathrm{H}_{2} \mathrm{O}$ of the descending or second ascending

\footnotetext{
1 Difference equals 2.7 and 2.5 times the standard error,
} respectively. 


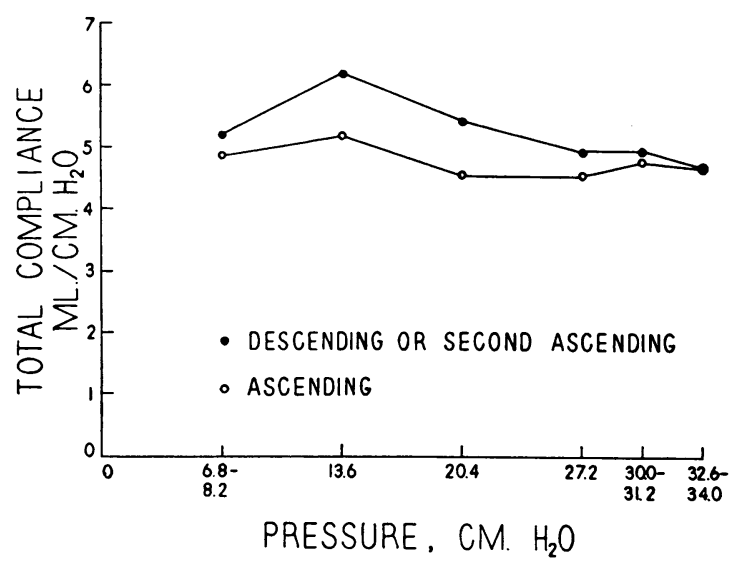

Fig. 3. Total compliance averages at various airWAY PRESSURES. Compliance is greater at a given pressure if the measurement is made following an inflation at a higher airway pressure.

series of measurements. This is an arbitrary comparison point used by other investigators (1) and selected here for two reasons. It was the midpoint of the pressure range used and, therefore, should be less affected by variables which might appear at either extreme of the pressure range. Also, there was a sufficiently wide range of values at this pressure to show correlation between compliance and physical characteristics, if such existed. There appeared to be no correlation between the total compliance at this pressure and the infant's age, weight or height.

\section{DISCUSSION}

The purpose of these experiments was to measure the total lung and chest wall compliance of infants, a facet of infant respiratory physiology previously not reported. In order to eliminate muscular effort, large doses of a neuromuscular blocking agent were employed.

Data are available to suggest that true compliance values can be obtained only if the volume of inflation is measured after the lungs and chest wall have been permitted to adjust to the applied pressure for 5 or more seconds. Butler and Smith (2) noted in adults that airway pressure would decline shortly after the lungs were distended with a given volume increment. This they attributed to the gradual opening of collapsed segments on the lung surface, with a consequent increase of effective alveolar volume. Airway pressure stabilized after 2 or 3 seconds. High intrapulmonary pressure in the supine adult also may result in the displacement of an appreciable amount of blood out of the thorax, which would lead to an increase in compliance (1). Similar effects might be expected in the infant. In order to minimize or eliminate variables which might result from an airway pressure of short duration, such as differences in tissue friction, resistance to movement, alveolar cohesiveness, pulmonary blood volume, and collapsed segments on the lung surface, we have recorded each volume measurement after chest inflation had been maintained for 10 seconds.

Pulmonary compliance values depend upon whether measurements are made from the normal resting volume or following a deep inspiration. Similarly, total compliance values vary depending upon whether positive pressure inflation is applied at the thoracic resting volume or following a previously greater expansion of the lungs and thorax. Butler (8) observed that the lungs and chest wall of adults, upon passive deflation, do not return immediately to their initial resting values after inflation to $20 \mathrm{~cm} \mathrm{H}_{2} \mathrm{O}$ pressure. During chest expansion, relaxed muscles stretch and abdominal contents are displaced downward. Relaxed muscle which has undergone distortion does not regain at once its original length when tension is released. In addition, frictional and surface tension forces oppose the return of displaced abdominal contents and result in a time-dependent deformation after inflation. A return to resting values occurs after about 10 seconds. In this study, usually less than 10 seconds elapsed between complete passive deflation and subsequent inflation. Consequently, volume measurements in the descending and second ascending series probably were affected somewhat by the residual distortion of the lung, chest wall and abdominal contents from the preceding higher pressure.

Total compliance values are greater if one progresses from the high pressure-volume recordings toward the lower ones, rather than in the opposite direction. Artifacts consequent to surface tension and lung blood volume are reduced by this technique, thereby affording more reliable data. The pressure-volume curves obtained in this study resemble those reported by Agostoni (9) for anesthetized, paralyzed newborn dogs. The total compliance of these newborn dogs was low over the tidal volume range during the initial ascending 
scrices of pressure-volume measurements, but a marked increase in the slope of the curve occurred at higher inflation pressures, indicating the opening of previously nonaerated alveoli. After a full expansion was over, compliance values were greater in the subsequent pressure-volume measurement, implying that most of these alveoli remained open.

Several investigators $(4,6,7)$ have concluded that pulmonary compliance is related to functional residual capacity, which in turn is related to an exponential function of body height (6). Although in our study there was a range of 71 days in age, 7 pounds in body weight, and $14 \mathrm{~cm}$ in height, no significant correlation could be found between the total compliance value at $20.4 \mathrm{~cm}$ $\mathrm{H}_{2} \mathrm{O}$ and age, weight or height. Possibly the number of infants studied was too small to reveal such a correlation.

Pulmonary compliance in newborn infants has been measured by others $(4,5)$. Our data suggest that the pulmonary and total compliance of the supine infant are nearly the same. Cook and his associates (4) found an average pulmonary compliance of $5.2 \mathrm{ml}$ per $\mathrm{cm} \mathrm{H}_{2} \mathrm{O}$ during quiet respiration in 18 infants aged 1 hour to 7 days. Swyer, Reiman and Wright (5) measured a pulmonary compliance of $4.9 \mathrm{ml}$ per $\mathrm{cm} \mathrm{H}_{2} \mathrm{O}$ in 15 sleeping infants aged 2 hours to 11 days. In both studies the values were calculated from the ratio of tidal volume to the change in intraesophageal pressure measured between points of no flow, i.e., at the extremes of tidal volume. Although in both of these groups the infants were younger than those in our study, we have thought it worthwhile to compare their results for pulmonary compliance and ours for total compliance. For this purpose, $6.8 \mathrm{~cm} \mathrm{H}_{2} \mathrm{O}$ positive airway pressure most closely approximates the negative change in intraesophageal pressure observed by the above two groups. At this airway pressure, our average total compliance was $5.2 \mathrm{ml}$ per $\mathrm{cm} \mathrm{H}_{2} \mathrm{O}$ when immediately preceded by a higher pressure, and $4.9 \mathrm{ml}$ per $\mathrm{cm}$ $\mathrm{H}_{2} \mathrm{O}$ when not immediately preceded by a higher pressure. These values approximate closely those reported for the infant's pulmonary compliance. This indicates that the compliance for the thorax, alone, is high in infants. A high chest wall compliance has been measured in newborn dogs (9).

The influence of the diaphragm and abdominal contents on respiratory expansion in the supine infant is presumed to be about the same whether the infant is breathing spontaneously or by positive pressure inflation in the presence of apnea. The major factor to overcome in either case is the hindrance of diaphragmatic excursion by the inertia and frictional resistances of the abdominal contents. Therefore, the similarity between pulmonary and total compliance in the infant implies that the infant's thorax has little influence on pulmonary expansion because of its characteristic anatomical structure (i.e., horizontally placed ribs and cylindrical shape).

\section{CASE PRESENTATION}

Decreased pulmonary compliances have been reported in infants with respiratory disease $(4,10,11)$. The following case report describes an infant demonstrating decreased total compliance 12 hours before signs of respiratory disease became evident.

This 7 pound 4 ounce male, with an imperforate anus, was admitted to this hospital within 8 hours of his birth. There was no evidence of pulmonary disease or abdominal distention by history, physical examination or roentgenogram. An anoplasty was performed when the infant was approximately 24 hours old. Atropine, $0.15 \mathrm{mg}$, was given intramuscularly 30 minutes prior to induction of anesthesia with cyclopropane and oxygen. The technique of anesthetic induction and tracheal intubation was by the method described for compliance studies. Succinylcholine, $6.0 \mathrm{mg}$ per pound of body weight, was given intramuscularly in two doses.

Compliance measurements were made within 4 minutes of the first injection of muscle relaxant. The pressures used were 6.8, 13.6, 20.4, 27.2 and $34.0 \mathrm{~cm} \mathrm{H}_{2} \mathrm{O}$, starting and ending at the highest pressure. The compliance values for the descending series were 3.1, 3.1, 3.5, 3.2 and $2.9 \mathrm{ml}$ per $\mathrm{cm} \mathrm{H}_{2} \mathrm{O}$; the values for the ascending series were $2.9,3.1,3.0,3.1$ and $2.9 \mathrm{ml}$ per $\mathrm{cm} \mathrm{H}_{2} \mathrm{O}$. The reason for the decreased compliance was not immediately evident.

Anesthesia and operation were continued without complications, and the postoperative course seemed normal for the first 12 hours. At this time the infant's respirations became labored, his chest retracted with each breath, and copious respiratory secretions developed. This respiratory distress progressively became worse over the next 12 to 20 hours, and several laryngoscopic tracheal aspirations were necessary to remove the thick secretions. It was feared that this represented hyaline membrane disease, but a chest roentgenogram was interpreted as "slight pulmonary hyperaeration." By 36 hours after operation, and following antibiotic therapy and aspiration of respiratory tract secretions, the infant's symptoms began to subside, and by 48 hours after operation, his condition was improved markedly.

Whatever the cause of this infant's respiratory prob- 
lem, we were able to demonstrate that the total compliance was decreased appreciably 12 hours before the onset of clinical respiratory symptoms.

\section{SUMMARY}

Measurements of the total lung and chest wall compliance at various airway pressures in 21 normal infants paralyzed with succinylcholine have been reported. Data are presented which show that the average total compliance for a given airway pressure is greater when immediately preceded by an inflation at a higher airway pressure than by one at a lower airway pressure. The similarity between values for pulmonary ànd total compliance in the infant is noted and discussed. In addition, a case has been presented in which a decreased total compliance was measured in an infant 12 hours before signs of respiratory disease became evident.

\section{REFERENCES}

1. Nims, R. G., Conner, E. H., and Comroe, J. H., Jr. The compliance of the human thorax in anesthetized patients. J. clin. Invest. 1955, 34, 744.

2. Butler, J., and Smith, B. H. Pressure-volume relationships of the chest in the completely relaxed anaesthetised patient. Clin. Sci. 1957, 16, 125.

3. Ferris, B. G., Jr., Mead, J., Whittenberger, J. L., and Saxton, G. A., Jr. Pulmonary function in convalescent poliomyalitic patients. III. Compliance of the lungs and thorax. New Engl. J. Med. 1952, 247, 390.

4. Cook, C. D., Sutherland, J. M., Segal, S., Cherry, R. B., Mead, J., McIlroy, M. B., and Smith, C. A. Studies of respiratory physiology in the newborn infant. III. Measurements of mechanics of respiration. J. clin. Invest. 1957, 36, 440.

5. Swyer, P. R., Reiman, R. C., and Wright, J. J. Ventilation and ventilatory mechanics in the newborn: Methods and results in 15 resting infants. J. Pediat. 1960, 56, 612.

6. Marshall, $R$. The physical properties of the lungs in relation to the subdivisions of lung volume. Clin. Sci. 1957, 16, 507.

7. Cook, C. D., Helliesen, P. J., and Agathon, S. Relation between mechanics of respiration, lung size and body size from birth to young adulthood. J. appl. Physiol. 1958, 13, 349.

8. Butler, J. The adaptation of the relaxed lungs and chest wall to changes in volume. Clin. Sci. 1957, $16,421$.

9. Agostoni, E. Volume-pressure relationships of the thorax and lung in the newborn. J. appl. Physiol. 1959, 14, 909.

10. Karlberg, P., Cook, C. D., O'Brien, D., Cherry, R. B., and Smith, C. A. Studies of respiratory physiology in the newborn infant. II. Observations during and after respiratory distress. Acta paediat. (Uppsala) 1954, 43, suppl. 100, 397.

11. Drorbaugh, J. E., Cherry, R. B., Lucey, J. F., Segal, S., Sutherland, J. M., and Smith, C. A. "Vital capacity" and lung compliance in normal newborn infants and infants with "hyaline membrane syndrome" (abstract). A. M. A. J. Dis. Child. 1957, 94, 434. 